\title{
GRI Sustainability Reporting by INGOs: A Way Forward for Improving Accountability?
}

\author{
Albert Anton Traxler $^{1} \cdot$ Dorothea Greiling $^{1} \cdot$ Hannah Hebesberger ${ }^{1}$
}

Published online: 5 March 2018

(C) The Author(s) 2018. This article is an open access publication

\begin{abstract}
Considering that the members of the International Non-Governmental Organizations (INGO) Accountability Charter played a prominent role in initiating the first sector supplement of the Global Reporting Initiative for non-governmental organizations (NGO), the purpose of the paper is to investigate their sustainability reporting (SR) practices in order to evaluate to what extent INGO Charter members comply with this voluntary accountability standard for SR. The empirical analysis is based on a content analysis of sustainability reports. The findings indicate that most of the INGO Charter members are far away from a comprehensive reporting practice. Hence, critical voices could assert that their reporting behavior seems to be more in line with facade building than the idea of providing a comprehensive account. By adapting a multiperspective theoretical discourse about the potential and shortcomings of SR to the NGO context, the study contributes to a field-specific theory-based pluralistic critical evaluation of SR as a major cross-sectoral innovation in voluntary accountability initiatives.
\end{abstract}

Keywords Content analysis - Critical accounting research · GRI NGO sector supplement · Nongovernmental organizations - Sustainability reporting

Albert Anton Traxler

albert.traxler@jku.at

Dorothea Greiling

dorothea.greiling@jku.at

Hannah Hebesberger

hannah.hebesberger@jku.at

1 Institute of Management Accounting, Johannes Kepler University, Linz, Austria

\section{Introduction and Research Question}

In the past decades, accountability pressure on non-governmental organizations (NGO) has increased considerably. NGOs are no longer obviously regarded as trustworthy. Rendering account has become a highly salient issue for most NGOs including the necessity to become more transparent for their own social and environmental performance (Crespy and Miller 2011; Gugerty 2009; Manetti and Toccafondi 2014; Unerman and O'Dwyer 2010). Highly publicized scandals — bad lemon problemsapparent or real mission drifts and changing government relationships in the wave of new public management reforms have contributed to this (Conway et al. 2015; Murtaza 2012; Schmitz et al. 2012). In addition, NGOs have been quite active in lobbying for an improved social and environmental accountability of for-profits. Nowadays, they are confronted with the demand to account for their own sustainability performance (Crespy and Miller 2011; Simaens and Koster 2013).

Accountability is an elusive multidimensional concept with multiple facets and many faces (Ebrahim 2010). According to Bovens (2007: 450), accountability is "a relationship between an actor and a forum, in which the actor has the obligation to explain and to justify his or her conduct, the forum can pose questions and pass judgments and the actor may face consequences." With respect to the external accountability forum, Unerman and O'Dwyer introduced three forms, namely upward, downward and holistic accountability (Unerman and O'Dwyer 2006, 2010). Upward accountability is target to external stakeholders who provide the funds of nonprofits (e.g., governments, donors and other providers of crucial resources) (Unerman and O'Dwyer 2010). For Unerman and O'Dwyer (2010) upward accountability is often 
directed at the efficiency of how the funds are spent. Upward accountability often dominates the mandated NGOs' reporting practices (Ebrahim 2010). The relevant stakeholders of downward accountability are clients or beneficiaries (Ebrahim 2010; Unerman and O'Dwyer 2010). While upward and downward accountability have a narrower stakeholder focus, a broader stakeholder focus is given in the case of holistic accountability. This type of accountability recognizes that NGOs have an impact on a broader range of stakeholders, than those directly addressed by upward or downward accountability. It ideally embraces multidirectional dimensions of accountability (Unerman and O'Dwyer 2010).

With respect to accountability, the track record of NGOs is not a good one. Back at the turn of the millennium, Salamon et al. (2000) classified the accountability gap of NGOs as one of the four key failures of philanthropic organizations. Insufficient transparency on the organizational level is still a relevant topic today. In their recent analyses of annual reports of NGOs Conway et al. (2015), Dhanani and Connolly (2015) and Tremblay-Boire and Prakash (2015) found signs of unbalanced and weak accountability practices. Reports are too much focused on the user needs of powerful funders, influenced by media attention, sometimes misleading or more in line with an impression management than providing an overall, unbiased picture of NGOs performance.

In the last decades, mandated public accountability obligations have multiplied (Carman 2007; Greiling and Stötzer 2015; Smith 2010a, b). In addition to this, voluntary accountability initiatives of NGOs have mushroomed as a form of self-regulation (Gugerty 2009). In the area of voluntary accountability standards outside the NGO sector, the development of sustainability reporting (SR) has broadened the reporting focus considerably across the sectors. "A sustainability report is a report published by a company or organization about the economic, environmental and social impacts caused by its everyday activities. [...] It [...] presents the organization's values and governance model, and demonstrates the link between its strategy and its commitment to a sustainable global economy." (GRI 2017: n. p.)

Organizations can chose from a substantive variety of SR standards. SR guidelines are seen as a reaction toward stakeholder pressures and offer reputational, competitive, political and market opportunities (Burritt and Schaltegger 2010). Today, the Global Reporting Initiative (GRI) guidelines are the most widely accepted standard. The most recent KPMG survey of corporate responsibility reporting shows that more than $90 \%$ of the G250, the world largest companies, publish a sustainability report. GRI guidelines are used by nearly three quarters of them (KPMG International 2015).
That NGOs also be engaged in SR is seen as a matter of fairness (Crespy and Miller 2011; Kolk 2008). In comparison to the large body of literature focusing on SR in corporations (e.g., Gatti and Seele 2014; Kolk 2010, 2008; Lozano 2013; Schwindenhammer 2013) and the increasing number of studies examining SR practices in the public sector (e.g., Goswami and Lodhia 2014; Greiling et al. 2015; Guthrie and Farneti 2008), researchers have paid little attention to NGOs. NGOs' reporting performance is not overwhelming. Reporting practice of NGOs is lagging behind the one of global companies, is unbalanced and not in line with an effective stakeholder engagement (Crespy and Miller 2011; Manetti and Toccafondi 2014; Simaens and Koster 2013).

While there is an extensive body of research on the functionality and dysfunctionality of accountability obligations in NGO government relations (Greiling and Stötzer 2015), the body of research on sector-specific voluntary accountability initiatives, also called accountability clubs, is much smaller (Crack 2017; Gugerty 2009; Prakash and Gugerty 2010; Tremblay-Boire and Prakash 2015). In voluntary accountability clubs NGOs jointly design accountability standards which regulate the entrance requirements, what is account for and whether and how non-compliance is monitored and sanctioned. The main reference theory for analyzing voluntary accountability standards of NGOs is club theory-in combination with signaling and principal-agency theory (Gugerty 2009; Tremblay-Boire et al. 2016; Crack 2017). A central question in this vein of research is what the characteristics of weak and strong accountability clubs are. By joining an accountability club, NGOs aim at increasing their reputation in order to increase their funding and for preempting threats of NGO accountability obligations (Crack 2017; Gugerty 2009; Prakash and Gugerty 2010).

Research on NGOs' voluntary accountability standards often compares different accountability clubs. Only Crack (2017) exclusively focuses on a specific group of international non-governmental organizations, by examining the members of the International Non-Governmental Organizations (INGO) Accountability Charter (hereafter INGO Charter). The INGO Charter "[...] is an initiative of international NGOs demonstrating their commitment to transparency, accountability and effectiveness." (INGO Accountability Charter 2015a: n. p.) It takes the view that a strong accountability practice is an essential element for legitimacy, quality of work and the trust, on which NGOs depend (INGO Accountability Charter 2015b). Any NGO can become an INGO Accountability Charter member if it fulfills several criteria (INGO Accountability Charter 2015c). Among those is the requirement that a NGO has to provide a sustainability report according to the GRI NGO sector supplement. 
INGOs are NGOs which are operating in multiple countries and sectors, like development or environmental (Walton et al. 2016). Clark evaluated the motivations of the INGO Charter members for joining, the perceived benefits of membership and the members' attitude on the Charter's efficacy. Twenty-six in-depth interviews showed that Charter membership provides a defense against actual or anticipated criticism of poor accountability from powerful external stakeholders and also an opportunity for organizational learning. Some members stressed that complying with the Charter's accountability demands is a resource intensive bureaucratic exercise, and expressed their frustration with the low profile of the Charter for donors and staff (Crack 2017). Therefore, the contribution of reducing the accountability gap has not been as effective as wanted.

Compared to the broad body of literature focusing on national or field-specific (e.g., social services, sport clubs, housing, education) studies on performance reporting of NGOs, the evaluation of accountability practices of INGOs is an under-researched area and not in line with the importance of INGOs. "Over the last 20 years [...] many INGOs $[\ldots]$ have grown enormously in size and influence. INGOs are consistently rated as the most trusted sector in global public trust surveys, yet are felt by many to be unaccountable." (INGO Accountability Charter 2015a: n. p.)

INGOs are powerful actors in global civil society and quite influential at shaping global governance mechanisms (Dhanani and Connolly 2015; Doh and Teegen 2002; Unerman and O'Dwyer 2006). They have gained significant power in transforming global politics and economics (Edwards and Fowler 2002; INGO Accountability Charter 2015a; Schmitz et al. 2012). The INGO Charter members-as a prominent subgroup of all INGOs-acknowledge explicitly in their Charter that INGOs are under particular accountability pressure and see their Charter as an attempt to reduce this accountability vacuum for themselves and other INGOs.

In contrast to Clark's study which evaluates the effectiveness of a sector-specific voluntary accountability club, this paper focuses on the compliance of INGO Charter members with another, much more known voluntary accountability standard, namely the compliance with the SR guidelines of the GRI. Back in May 2010, GRI issued the first NGO sector supplement. The NGO sector supplement aims at both demonstrating NGOs' commitment to strengthen their own accountability and meeting society's demand to making NGOs more accountable for their actions (GRI 2010, 2014). It “[...] is a reporting system developed to be applicable principally to international NGOs or medium to large national NGOs. However, the Supplement may be useful to any NGO which wishes to improve its accountability and sustainability." (GRI 2010:
6) Members of the INGO Accountability Charter are obliged to report on their sustainability performance on basis of NGO sector supplement (INGO Accountability Charter, 2015b).

According to the GRI and the INGO Charter, which was later renamed in Accountability Now, the INGO Charter played a prominent role in initiating and designing the first GRI NGO sector supplement (Accountable Now 2017; GRI 2010) as a sector standard which goes beyond the selfregulation of the INGO Charter members. By complying with the sector supplement, NGOs aim at demonstrating that they meet the same standards of transparency they demand from governments and business.

Considering the prominent role the INGO Charter played for the first NGO sector supplement and the mandatory application of it for the members, the guiding research question is:

To what extent do the INGO Accountability Charter members comply in their reporting practice with the NGO sector supplement?

To address this research question, we present the results of a content analysis of GRI reports published by INGO Charter members. We are mainly interested to find out whether the Charter members report in a comprehensive way or only disclose selective core indicators of the NGO sector supplement.

The remainder of the paper is structured as follows. Section II provides an outline on theory-based discourses of reasons for SR and potential shortcomings. This is followed by a description of our sample and the research methodology applied (section III), including a short description of the NGO sector supplement. In section IV our findings are presented, followed by a discussion, conclusions, limitations of our study and directions for further research in section $\mathrm{V}$.

With our study we augment to the academic debate in the following ways: We contribute to the small body of empirical studies evaluating SR as an emerging practice for NGOs. To our knowledge, this is the first study that presents findings on the adoption of the GRI NGO sector supplement. Additionally, we investigate how a very prominent group, the INGO Charter members, complies with the NGO sector supplement, a standard they have initiated. Despite their size and an influence shaping global governance mechanisms, INGOs are an under-researched field when it comes to evaluating their reporting practices performance. In particular, this is the case with respect to SR as an important voluntary cross-sectoral accountability practice. Another contribution is that we adapt a multitheoretical discourse of reasons for SR and shortcomings of SR to the NGO context. Prior studies on SR of NGOs had a much more selective theoretical focus 
and neglected the critical accounting discourse. Our study contributes to a theory-based pluralistic critical evaluation of SR as a major innovation in voluntary accountability initiatives across the sectors. INGOs as large and influential actors are under a particular pressure how transparent they are in comparison with private for-profits firms and public entities.

\section{Theoretical Discourses of SR by INGOs}

In the theoretical discussion about the motives of SR, there are two schools of thought. The first one stresses the instrumental value of SR for the reporting entity and sees it as a way for improving accountability. It has an overlap with arguments which can be found also in the small body of research using club theory for evaluating the effectiveness of accountability clubs of NGOs. Common topics with the club theorist are that SR might contributes to reducing information asymmetries of stakeholders and that SR is used for reputation building and therefore for getting a better access to financial resources.

The second school in the academic debate about SR is much more critical, questioning whether SR is a worthwhile endeavor or just a management fad which will disappear over time (Burritt and Schaltegger 2010). This school of thought stresses the biased and unbalanced nature of SR, regards it as greenwashing, window dressing or facade building and therefore does not trust that SR contributes in a meaningful way toward an improved accountability.

Two prominent referenced theories in the first school of thought are principal-agency theory and signaling theory. In the focus of the discussions of SR based on principalagency theory are the information asymmetries between the reporting entity and its principals. INGOs are in principal-agent relationship with multiple principals or external stakeholders-donors, beneficiaries, public funders, etc.-who have information disadvantages as outsiders. Mandated accountability obligations and voluntary accountability clubs are attempts to deal with these information asymmetries. SR addresses information asymmetries regarding the organization's impacts on sustainable development and its triple bottom line performance (Hahn and Kühnen 2013). This line of thought is also taken up by club theorists, who discuss the role of voluntary accountability programs as one attempt to mitigate the information problem (Crack 2017; Gugerty 2009). Voluntary information disclosure increases the information basis for the users of SR and allows them to screen the reported content for forming judgment about the triple bottom line performance.
Signaling theory had its origin in dealing with information asymmetries in the labor market (Spence 1973), but was soon extended to many other fields including voluntary reporting initiatives of organizations. Sustainability reports are a disclosure tool to influence the perception of an organization's sustainability performance by providing information about its triple bottom line performance, its commitment toward sustainability and its activities as a good citizen (Comyns et al. 2013; Comyns and Figge 2015; Mahoney et al. 2013; Simaens and Koster 2013; Verrecchia 1983). For the INGO context Simaens and Koster (2013) suggest that SR might increase the possibilities to get a better access to (financial) resources (Simaens and Koster 2013). Considering the importance of INGOs as global civil society actors with lobbying for better governance mechanism for a more sustainable planet, one would expect that they are particularly interested in signaling their sustainability performance.

In the INGO context, joining an accountability club is regarded as a reputational signal (Crack 2017). Information asymmetries by stakeholders result in situations that they cannot distinguish easily high-quality organizations from low-quality ones (Gugerty 2009). High-quality INGOs have an interest to differentiate themselves from bad lemons operating in the sector by joining a voluntary accountability initiative (Prakash and Gugerty 2010). Such a reputational signaling imposes costs for the reporting entity. The body of research on NGO accountability programs discusses factors determining the effectiveness of accountability clubs and factors influencing the credibility of a signal. To the credibility of the signal contributes the strength of the standard-rules for entry and complianceand the robustness of the monitoring, verification and sanctioning system (Gugerty 2009; Prakash and Gugerty 2010; Tremblay-Boire et al. 2016). Higher compliance costs, in form of fees and demanding reporting requirements, affect the credibility positively (Gugerty 2009). The literature on NGO accountability clubs also stresses that the credibility of a signal is impaired if monitoring and sanctioning mechanisms are weak. Empirical findings show that this is often the weak spot of voluntary selfregulation initiatives of NGOs (Gugerty 2009; TremblayBoire et al. 2016).

A third prominent reference theory for the discussion of the benefits of SR is stakeholder theory. Stakeholder theory is an umbrella term for a variety of approaches which stresses that organizations which take good care of a broad group of internal and external stakeholders will create more value. The most prominent line within stakeholder theory is strategic stakeholder theory which was made popular by Freeman (1984, 1994, 2010). Managing stakeholder relations is regarded as a critical part for a firm's ongoing success, for securing a continuous flow of resources and for 
creating a strategic positioning advantage (Freeman et al. 2004). Considering the rising interest of stakeholders on sustainability issues, SR is seen as an instrument to provide strategically relevant stakeholders with information on an organization's triple bottom line performance. SR broadens the perspective beyond the financial bottom line and considers the concerns of a larger number of stakeholders (Hahn and Kühnen 2013; Van der Laan Smith et al. 2005). Normative stakeholder theory with its roots in business ethics stresses the intrinsic value of stakeholder orientation. Normative stakeholder theory focuses on the principle of fairness and regards it as essential that the legitimate claims of all stakeholders should be equally addressed (Cragg 2002). This kind of argumentation is in line with the ideas of holistic accountability.

Today, INGOs as multiple stakeholder organizations are confronted with a wide range of heterogeneous stakeholder accountability demands and expectations to provide a better information basis for their stakeholders' decisionmaking process. Prior research on performance accountability of NGOs shows that the reporting practices of NGOs are often focused on the information needs of powerful funders and therefore on upward accountability (Ebrahim 2010). Concerning the SR practices the study of Manetti and Toccafondi (2014) who analyzed the stakeholder engagement process of 54 NGOs drawn from the GRI database confirmed a prevalence of a strategic stakeholder management approach or in other words a selective reporting practices. Contrastingly, the study by Simaens and Koster (2013) concluded that SR has a broad user focus which they regard as signs for holistic accountability.

Compared to the so far referred theories, legitimacy theory broadens the perspective by focusing on an organization's contract with the society at large (Gray et al. 1995). Legitimacy theory stresses that organizations have to demonstrate that their actions are in line with prevailing social norms, beliefs and values. A substantial incongruence between societal expectations and the observable organizational actions results in a legitimacy gap. This can endanger an organizations permission to exist (Cho et al. 2015; Dowling and Pfeffer 1975). Legitimacy is seen as an essential resource for the survival of an organization (Deegan 2014; Dowling and Pfeffer 1975). INGOs often operate in legitimacy-sensible areas. Since a loss of legitimacy can lead to the ruin of an organization, INGOs must spend much attention to maintain or enhance their legitimacy (Lecy et al. 2012). Voluntary disclosures are one instrument for dealing with a legitimacy gap (Crespy and Miller 2011; Deegan 2014).

In the social and environmental literature SR is put in the context of an active legitimation management strategy for ensuring an organization's survival (Deegan 2014). Disclosure of NGOs about their sustainability performance is regarded as essential because they have been active in asking corporation doing so (Crespy and Miller 2011, Simaens and Koster 2013). If NGOs do not disclose, they threaten their ability of having a legitimate voice in the dialogue about sustainable development (Crespy and Miller 2011).

The roles as initiators and influential designers of the NGO sector supplement for which the INGO Charter formed a partnership with GRI puts the INGO Charter members under pressure to be role models. All other practices would potentially threaten their legitimacy, because INGOs would diverge from sustainability-accountability expectations they have created themselves. A comprehensive accountability practice is also supported by the lines of arguments which are referring to the other three theories presented. A more comprehensive compliance increases the information base for the users and provides more signals to the stakeholders. Compliance to a voluntary accountability standard, in our case the NGO sector supplement, is one factor which positively influences the credibility of a signal. INGOs have a quite heterogeneous group of stakeholders they have to account for with heterogeneous information needs regarding their sustainability performance.

In contrast to the so far instrumental school of thoughts, critical accounting scholars questioned the value-adding contributions of SR in general. This starts with the doubt that sustainability as a global concept is applicable at the corporate level (Gray and Milne 2002). With respect to the corporate level, common lines of critiques are that $\mathrm{SR}$ is a public relations or investor relation endeavor without substance, a greenwashing or window dressing attempt, an strategic impression management tactic or a management fad which will disappear over time (Baker 2010; Burritt and Schaltegger 2010; Gray 2010; Gray and Milne 2002; Hopwood 2009). Although in large commercial organizations SR has become an institutionalized element of disclosures, global environmental indicators are in the decline (Cho et al. 2015). Also on a fundamental level Gray (2013) questions whether SR contributes in any meaningful way to accountability. The voluntary nature of SR makes room for selective, incomplete and biased disclosures, strategically omitting potentially damaging information of their environmental performance and over-reporting positive aspects (Cho et al. 2015; Guidry and Patten 2010; Lyon and Maxwell 2011). Such a reporting practice is regarded as problematic because inaccurate and misleading disclosures can lead to erroneous assessments by stakeholders.

The amount of organizational hypocrisy and facade building which can be found in SR is for Cho et al. (2015) a way of managing conflicting stakeholder interests. Whether facade building works or not depends on how obvious the discrepancy between a company's "talk" and its actions is. 
Table 1 INGO Charter members

\begin{tabular}{|c|c|c|c|c|}
\hline Name & Fields of activity & Budget 2015 & Countries with national office & Source main income \\
\hline $\begin{array}{l}\text { Action aid } \\
\text { international }\end{array}$ & $\begin{array}{l}\text { Inequality; food and land rights; } \\
\text { women's rights; democratic } \\
\text { governance; education; emergencies } \\
\text { and conflict; climate change; HIV and } \\
\text { AIDS; youth }\end{array}$ & $243,168,000 €$ & $\begin{array}{l}\text { Brazil, Belgium, Kenya, South Africa, } \\
\text { Thailand, UK }\end{array}$ & Committed giving \\
\hline $\begin{array}{l}\text { Amnesty } \\
\text { international }\end{array}$ & $\begin{array}{l}\text { Armed conflict; arms control; corporate } \\
\text { accountability; death penalty; } \\
\text { detention; disappearances; } \\
\text { discrimination; freedom of expression; } \\
\text { indigenous people; international } \\
\text { justice; living in dignity; refugees, } \\
\text { asylum seekers and migrants; sexual } \\
\text { and reproductive rights; torture }\end{array}$ & $278,000,000 €$ & $\begin{array}{l}\text { Hong Kong, Israel, Kenya, Lebanon, } \\
\text { Mexico, Senegal, South Africa, UK }\end{array}$ & $\begin{array}{l}\text { Regular and non- } \\
\text { regular donations } \\
\text { from individuals }\end{array}$ \\
\hline Article 19 & $\begin{array}{l}\text { Freedom of expression; media } \\
\text { regulation; freedom of information; } \\
\text { censorship, violence and press } \\
\text { freedom; governance and democracy; } \\
\text { discrimination; defamation; conflict } \\
\text { and security }\end{array}$ & $4,760,450 €$ & $\begin{array}{l}\text { Azerbaijan, Bangladesh, Brazil, } \\
\text { Kazakhstan, Kenya, Mexico, Senegal, } \\
\text { South Africa, Tunisia, UK }\end{array}$ & Governments \\
\hline BRAC & $\begin{array}{l}\text { Disaster management and climate } \\
\text { change; health, nutrition and } \\
\text { population; water, sanitation and } \\
\text { hygiene; agriculture and food security; } \\
\text { integrated development; microfinance; } \\
\text { enterprises and investments; targeting } \\
\text { the ultra poor; education; migration; } \\
\text { skills development; community } \\
\text { empowerment; gender justice and } \\
\text { diversity; human rights and legal aid } \\
\text { services; urban development; } \\
\text { governance, management and capacity } \\
\text { building }\end{array}$ & $586,035,420 €$ & $\begin{array}{l}\text { Afghanistan, Bangladesh, Liberia, } \\
\text { Myanmar, Nepal, Pakistan, } \\
\text { Philippines, Sierra Leone, South } \\
\text { Sudan, Sri Lanka, Tanzania, The } \\
\text { Netherlands, Uganda, UK, USA }\end{array}$ & $\begin{array}{l}\text { Donor grants, social } \\
\text { enterprises, } \\
\text { microfinance } \\
\text { programs }\end{array}$ \\
\hline $\begin{array}{l}\text { Care } \\
\text { international }\end{array}$ & $\begin{array}{l}\text { Women's empowerment; education; } \\
\text { food and nutrition security and climate } \\
\text { change; sexual and reproductive } \\
\text { health; maternal health; child health; } \\
\text { HIV/AIDS; monitoring, evaluating } \\
\text { and learning }\end{array}$ & $630,158,000 €$ & $\begin{array}{l}\text { Australia, Austria, Belgium, Canada, } \\
\text { Denmark, Egypt, France, Germany, } \\
\text { India, Indonesia, Japan, Morocco, } \\
\text { Norway, Peru, Sri Lanka, Switzerland, } \\
\text { Thailand, The Netherlands, UK, USA }\end{array}$ & $\begin{array}{l}\text { Government and non- } \\
\text { governmental } \\
\text { agencies grants, } \\
\text { donor contributions }\end{array}$ \\
\hline $\begin{array}{l}\text { CBM } \\
\text { international }\end{array}$ & Help for people with disabilities & $230,113,166 €$ & $\begin{array}{l}\text { Australia, Canada, Germany, Ireland, } \\
\text { Italy, Kenya, New Zealand, South } \\
\text { Africa, Switzerland, UK, USA }\end{array}$ & $\begin{array}{l}\text { Individual donors, } \\
\text { government } \\
\text { funding }\end{array}$ \\
\hline CIVICUS & $\begin{array}{l}\text { Protecting the rights of civil society; } \\
\text { strengthening civil society good } \\
\text { practices; increasing the influence of } \\
\text { civil society }\end{array}$ & $4,156,194 €$ & South Africa, Switzerland, UK, USA & Grants and donations \\
\hline educo & Children's rights; education & $28,392,761 €$ & $\begin{array}{l}\text { Bangladesh, Benin, Bolivia, Burkina } \\
\text { Faso, Cambodia, Ecuador, El } \\
\text { Salvador, Ghana, Guatemala, India, } \\
\text { Mali, Nicaragua, Peru, Philippines, } \\
\text { Spain }\end{array}$ & $\begin{array}{l}\text { Child sponsorship, } \\
\text { collaborators and } \\
\text { private companies }\end{array}$ \\
\hline $\begin{array}{l}\text { European } \\
\text { environmental } \\
\text { bureau }\end{array}$ & $\begin{array}{l}\text { Environmental problems: agenda } \\
\text { setting, monitoring, advising on and } \\
\text { influencing the way the EU deals with } \\
\text { these issues }\end{array}$ & $3,266,047 €$ & Belgium & $\begin{array}{l}\text { Foundations, EU } \\
\text { commission }\end{array}$ \\
\hline
\end{tabular}


Table 1 continued

\begin{tabular}{|c|c|c|c|c|}
\hline Name & Fields of activity & Budget 2015 & Countries with national office & Source main income \\
\hline $\begin{array}{l}\text { Greenpeace } \\
\text { International }\end{array}$ & $\begin{array}{l}\text { Climate change; forests; oceans; } \\
\text { agriculture; toxic pollution }\end{array}$ & $346,148,000 €$ & $\begin{array}{l}\text { Argentina, Australia, Austria, Belgium, } \\
\text { Brazil, Bulgaria, Canada, Chile, } \\
\text { China, Croatia, Czech Republic, } \\
\text { Democratic Republic of Congo, } \\
\text { Denmark, Finland, France, Germany, } \\
\text { Greece, Hong Kong, Hungary, India, } \\
\text { Indonesia, Israel, Italy, Japan, } \\
\text { Luxembourg, Lebanon, Malaysia, } \\
\text { Malta, Mexico, New Zealand, } \\
\text { Norway, Philippines, Poland, } \\
\text { Portugal, Romania, Russia, Senegal, } \\
\text { Slovakia, Slovenia, South Africa, } \\
\text { South Korea, Taiwan, Thailand, The } \\
\text { Netherlands, Turkey, Spain, Sweden, } \\
\text { Switzerland, UK, USA }\end{array}$ & Grants and donations \\
\hline $\begin{array}{l}\text { International } \\
\text { water and } \\
\text { sanitation } \\
\text { centre }\end{array}$ & $\begin{array}{l}\text { Water sanitation; hygiene services; } \\
\text { water security }\end{array}$ & $7,784,000 €$ & $\begin{array}{l}\text { Burkina Faso, Ethiopia, Ghana, The } \\
\text { Netherlands, Uganda }\end{array}$ & Foundations \\
\hline $\begin{array}{l}\text { OXFAM } \\
\text { International }\end{array}$ & $\begin{array}{l}\text { Fight poverty; human rights; gender } \\
\text { justice; provide clean water, food and } \\
\text { sanitation in disaster zones; fairer land } \\
\text { policies; action on climate change; } \\
\text { global food supplies; emergency } \\
\text { response }\end{array}$ & $\begin{array}{l}1,071,400,000 \\
€\end{array}$ & $\begin{array}{l}\text { Australia, Belgium, Brazil, Canada, } \\
\text { Denmark, France, Germany, Hong } \\
\text { Kong, India, Ireland, Italy, Japan, } \\
\text { Korea, Mexico, New Zealand, } \\
\text { Quebec, Spain, South Africa, Sweden, } \\
\text { The Netherlands, UK, USA }\end{array}$ & $\begin{array}{l}\text { Institutional } \\
\text { fundraising, public } \\
\text { fundraising }\end{array}$ \\
\hline $\begin{array}{l}\text { Plan } \\
\text { international }\end{array}$ & $\begin{array}{l}\text { Children's rights and equality for girls; } \\
\text { education; skills and work; youth } \\
\text { activism; sexual health and rights; } \\
\text { ending violence }\end{array}$ & $821,729,000 €$ & $\begin{array}{l}\text { Australia, Bangladesh, Belgium, Benin, } \\
\text { Bolivia, Brazil, Burkina Faso, Canada, } \\
\text { Cambodia, Cameroon, Central Africa } \\
\text { Republic, China, Colombia, Denmark, } \\
\text { Dominican Republic, Ecuador, Egypt, } \\
\text { El Salvador, Ethiopia, Finland, } \\
\text { France, Germany, Ghana, Guatemala, } \\
\text { Guinea, Guinea-Bissau, Haiti, } \\
\text { Honduras, Hong Kong, India, } \\
\text { Indonesia, Ireland, Italy, Japan, } \\
\text { Kenya, Korea, Laos, Liberia, Malawi, } \\
\text { Mali, Mozambique, Myanmar, Nepal, } \\
\text { Nicaragua, Niger, Nigeria, Norway, } \\
\text { Pakistan, Paraguay, Peru, Philippines, } \\
\text { Rwanda, Senegal, Sierra Leone, } \\
\text { Spain, Sri Lanka, South Sudan, Sudan, } \\
\text { Sweden, Switzerland, Tanzania, } \\
\text { Thailand, The Netherlands, Timor- } \\
\text { Leste, Togo, Uganda, UK, USA, } \\
\text { Vietnam, Zambia, Zimbabwe }\end{array}$ & $\begin{array}{l}\text { Child sponsorship, } \\
\text { grants (donations } \\
\text { from institutions } \\
\text { and cooperate } \\
\text { donors) }\end{array}$ \\
\hline $\begin{array}{l}\text { Sightsavers } \\
\text { International }\end{array}$ & Protecting sight; disability rights & $214,877,056 €$ & $\begin{array}{l}\text { Bangladesh, Dubai, Ireland, Italy, India, } \\
\text { Kenya, Pakistan, Senegal, Sweden, } \\
\text { UK, USA }\end{array}$ & Donation \\
\hline $\begin{array}{l}\text { SOS children's } \\
\text { village } \\
\text { international }\end{array}$ & $\begin{array}{l}\text { Children's rights; quality care; } \\
\text { safeguard children; teach and train; } \\
\text { protect children in emergencies }\end{array}$ & $\begin{array}{l}1,122,496,000 \\
\quad €\end{array}$ & $\begin{array}{l}\text { Austria (headquarters) and } 117 \\
\text { countries worldwide }\end{array}$ & $\begin{array}{l}\text { Governmental } \\
\text { subsidies for } \\
\text { domestic programs, } \\
\text { donations, } \\
\text { sponsorship }\end{array}$ \\
\hline $\begin{array}{l}\text { Transparency } \\
\text { international }\end{array}$ & Anti-corruption & $27,097,999 €$ & $\begin{array}{l}\text { Germany (international secretariat) and } \\
\text { more than } 100 \text { countries worldwide }\end{array}$ & $\begin{array}{l}\text { Government } \\
\text { agencies, } \\
\text { multilateral } \\
\text { institutions }\end{array}$ \\
\hline
\end{tabular}


Table 1 continued

\begin{tabular}{|c|c|c|c|c|}
\hline Name & Fields of activity & Budget 2015 & Countries with national office & Source main income \\
\hline $\begin{array}{l}\text { World Vision } \\
\text { International }\end{array}$ & $\begin{array}{l}\text { Child rights and equity; disaster } \\
\text { management; education and life skills; } \\
\text { health; justice for children; resilience } \\
\text { and livelihood; water and sanitation }\end{array}$ & $\begin{array}{l}2,730,000,000 \\
€\end{array}$ & $\begin{array}{l}\text { UK (headquarters) and nearly } 100 \\
\text { countries worldwide }\end{array}$ & $\begin{array}{l}\text { Donation (including } \\
\text { individuals, } \\
\text { corporations and } \\
\text { foundations) }\end{array}$ \\
\hline $\begin{array}{l}\text { The World } \\
\text { Young } \\
\text { Women's } \\
\text { Christian } \\
\text { Association }\end{array}$ & $\begin{array}{l}\text { Women's empowerment, leadership and } \\
\text { rights }\end{array}$ & $2,892,584 €$ & $\begin{array}{l}\text { Switzerland (headquarters) and } 120 \\
\text { countries worldwide }\end{array}$ & $\begin{array}{l}\text { Ecumenical support, } \\
\text { governments, co-op } \\
\text { agencies }\end{array}$ \\
\hline
\end{tabular}

In our case, the talk level is the prominent role the INGO Charter has played in initiating the NGO sector supplement. How the INGO Charter members comply with the NGO sector supplement in their reporting practice refers to the action level. Most stakeholders are spectators with a very limited first-hand experience of an organization's action (Cho et al. 2015), and thus, facade building might work for some time. Building on Abrahamson and Baumgard (2008) Cho et al. discuss three types of facades. The rational facade is direct to presenting an organization in line with efficiency and financial sustainability. The progressive facade is created when an organization early adopts SR as a relatively new (progressive) management technique for proactively addressing social and environmental concerns raised by critical stakeholders (Cho et al. 2015). The reputation facade is created when a reporting entity uses rhetorical symbols in SR desired by critical stakeholders (Cho et al. 2015). Under a critical lens, the prominent role the INGO Charter played in initiating the first NGO sector supplement, which was issued in May 2010, could be understood as progressive facade building because they helped to create a disclosure standard that was lacking so far for the INGO sector.

\section{Sample and Methodology}

Data collection took place in spring 2015. At this time 18 INGO Charter members had uploaded a report. We used the most recent reports of the members which were available at the homepage of the INGO Charter in March 2015. Table 1 shows the members at the time of data collection and their characteristics. The order of the NGOs does not equal the numbers in the spider charts of the findings section. For empirically investigating the research question, a content analysis of sustainability reports published by the INGO Charter members was performed. The content analysis, which "is a technique for gathering data that uses a set of procedures to make valid interferences from text"
(Guthrie and Abeysekera 2006: 115) is quite frequently applied for analyzing voluntary disclosures.

Since compliance with the NGO sector supplement was assessed, we chose a deductive approach with the indicators of the NGO sector supplement itself as underlying category system. The sector supplement consists of three different sections. The first section, strategy and profile, covers disclosures "that set the overall context for understanding organizational performance such as its strategy, profile, and governance." (GRI 2010: 24) The second section, management approaches, requires information about "how an organization addresses a given set of topics in order to provide context for understanding performance in a specific area." (GRI 2010: 24) The third section contains the performance indicators. Performance indicators are "Indicators that elicit comparable information on the economic, environmental, and social performance of the organization." (GRI 2010: 24) The standard disclosures regarding the profile include strategy and analysis, organizational profile, report parameters and governance, commitments and engagement. The disclosures concerning management approaches and performance indicators are assigned to four categories; program effectiveness, economic, environmental and social. The latter is split into the four subcategories, labor practices and decent work, human rights, society and product responsibility. The subcategories of the economic, environmental and social performance are the classical triple bottom line dimensions. As displayed in Annex I, a few adjustments for the NGO context have been made. Additionally the NGO sector supplement adds with program effectiveness a new subcategory, which is of particular relevance for the sector. By providing the required information NGOs can demonstrate that they are operating effectively and efficiently in line with their mission (GRI 2010).

The section of performance indicators includes core and additional indicators. Core indicators are regarded as material for most organizations as they are considered to be interesting to most stakeholders (GRI 2010). We solely used the core performance indicators of the NGO sector 


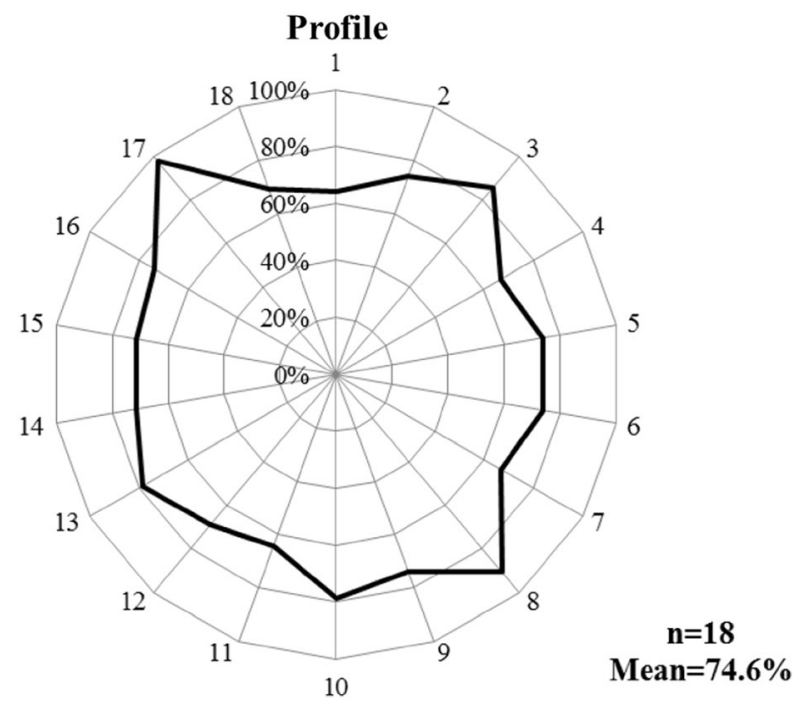

Fig. 1 Profile

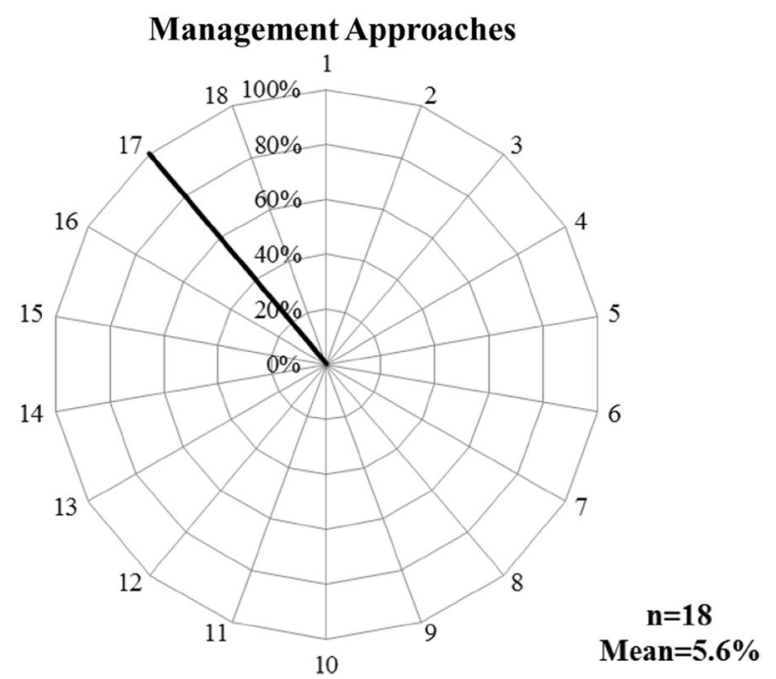

Fig. 2 Management approaches

supplement for the investigation because those are assumed to be material for most organizations (GRI 2010) (see Appendix). Thus, our assessment included 42 profile disclosures, seven management approaches and 63 core indicators ( $\sum 112$ assessment items). To assess the reports a two-tier scale was used, whereby 0 stands for an organization not giving information on a specific indicator and 1 for an organization doing it. Organizations which do not report on a specific indicator because this indicator was not material or applicable got a 1 , if reasons for non-reporting

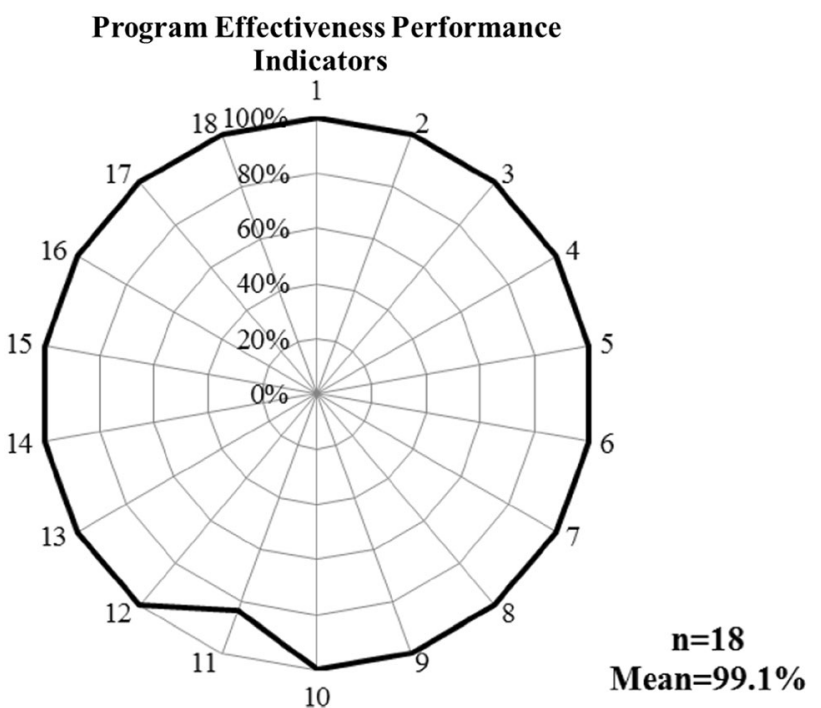

Fig. 3 Program effectiveness performance indicators

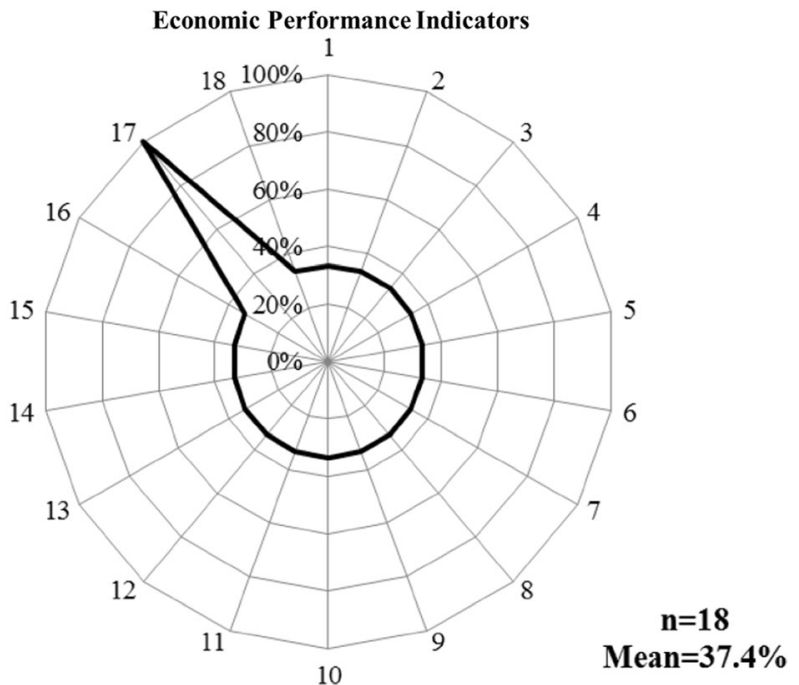

Fig. 4 Economic performance indicators

were stated. This approach made it possible for those organizations with a constrained field of activity to reach a high compliance score. For ensuring the reliability of the content analysis, we followed the suggestions by Guthrie and Abeysekera (2006) based on Milne and Adler (1999). Coding was done by two persons and discrepancies were discussed.

For each category levels of compliance were calculated as illustrated in the following example: 


\section{Example: Labor Practices and Decent Work}

Number of Labor Practices and Decent Work indicators: 11

Organization reports:

Organizations which follow the GRI guidelines can report on three different application levels, A, B or C. The level represents the extent of the application of the guidelines. Level A indicates the most in-depth application. According to the INGO Charter, INGO Accountability Charter members have to report at least on application level $\mathrm{C}$ which is far away from a comprehensive compliance (INGO Accountability Charter 2015b).

\section{Findings}

The numbers in the spider charts represent the results for each of the 18 INGO Charter members. For instance, Fig. 1 shows that report No. 17 scores almost $100 \%$ as it provides information on nearly every indicator of this category, while No. 1 reports on less than two-thirds. In addition, the mean values are indicated in the lower right hand corner of the charts.

The mean value of compliance for profile disclosures is almost $75 \%$ (cf. Fig. 1). Apart from the performance indicator category of program effectiveness, the category of profile disclosures reaches the highest mean degree of compliance. High compliance rates in this category are also reported in other content analyses across sectors. Much of the information in this category is easily accessible or already available for the examined INGOs. In contrast to profile disclosures, only one of the 18 INGOs reports on management approaches (cf. Fig. 2).

Within the categories of the performance indicators, program effectiveness reaches the highest mean value of compliance $($ mean $=99.1 \%)$. Only one INGO does not report on every indicator in this category (cf. Fig. 3). Seventeen of the 18 organizations report on one-third of the economic core performance indicators. Only one organization provides information on every single indicator in this category (cf. Fig. 4).

In comparison the environmental performance indicators show an even worse result. Many INGOs only cover one or two of the 17 core indicators $($ mean $=15 \%$ ) (cf. Fig. 5). Although INGOs are advocating for environmental concerns and exerting pressure on private and public organizations, they are unwilling to account for their own environmental impacts.

Moving to the social category within the group of performance indicators, the subcategory of labor practices and decent work performance indicators reaches a mean value of compliance of nearly $40 \%$ (cf. Fig. 6).

Concerning human rights performance indicators, only one member provides information (cf. Fig. 7). As in the case of the environmental performance indicators, it is astonishing that just one INGO reports on human rights performance indicators if we look at missions and chosen areas of activities of the INGO members. Figure 8 shows

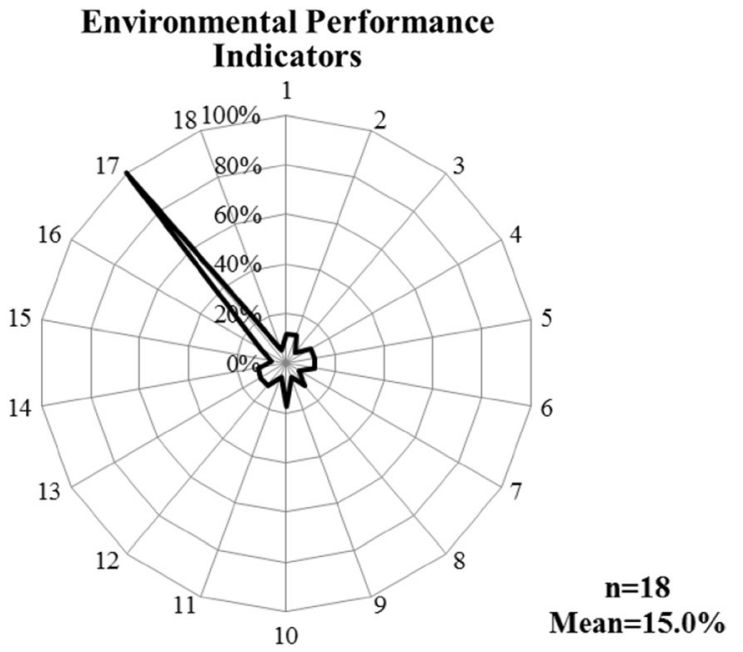

Fig. 5 Environmental performance indicators

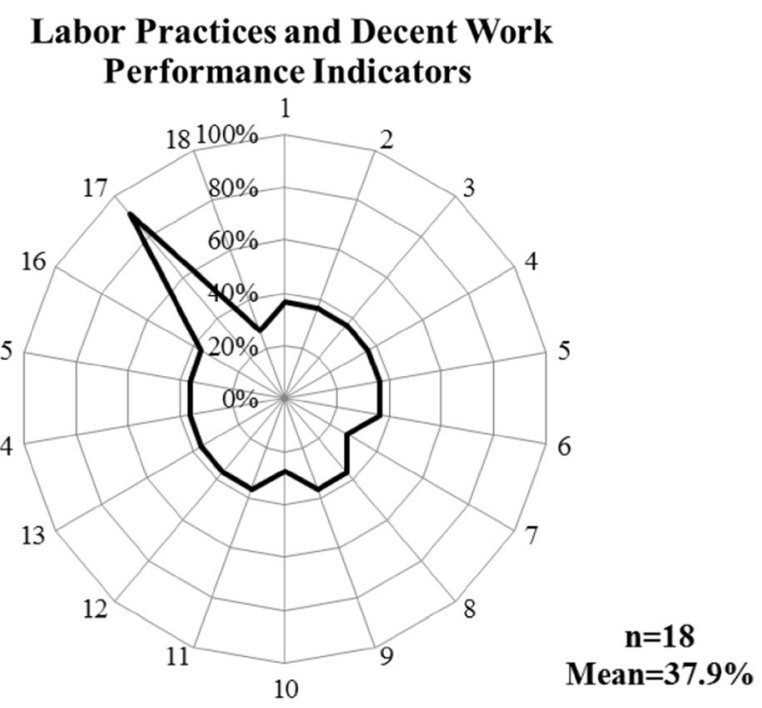

Fig. 6 Labor practices and decent work performance indicators 


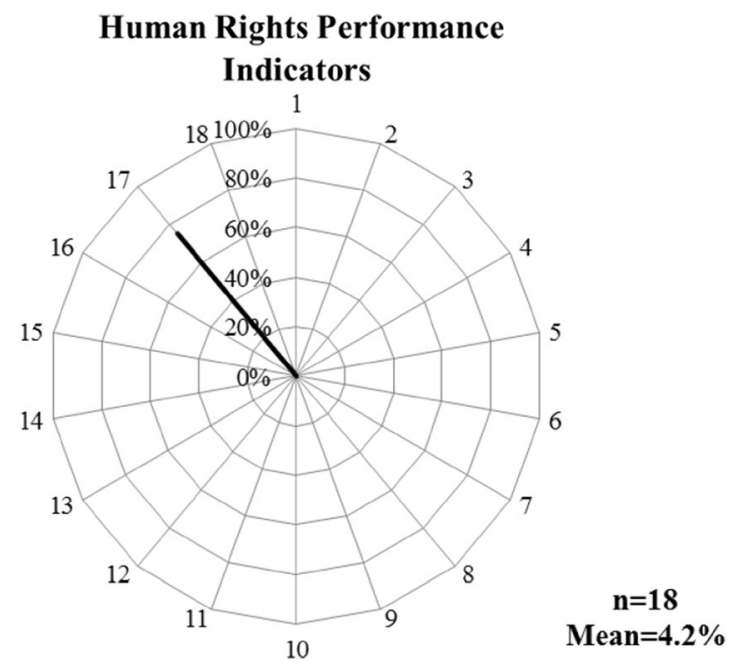

Fig. 7 Human rights performance indicators

that the mean value of society performance indicators rates about $35 \%$.

Seventeen of the 18 INGO Charter members provide only information for one quarter of the product responsibility performance indicators (cf. Fig. 9).

To investigate the balance between the three classical triple bottom line dimensions-economic, environmental and social-we calculated a mean value over all four social categories-labor practices and decent work, human rights, society and product responsibility - of the social dimension $([37.9 \%+4.2 \%+34.7 \%+29.2 \%] / 4=26.5 \% ; \quad$ cf. Figs. 6, 7, 8 and 9). The social dimension performs better than the environmental (15\%; cf. Fig. 5) but worse than the others two, namely program effectiveness performance indicators (99.1\%; cf. Fig. 3) and economic performance indicators (37.4\%; cf. Fig. 4).

Figure 10 shows an overview of the total compliance rate (TCR) of the organizations under review. The TCR was calculated by including the results of all nine categories equally. The mean value of the TCR is $37.5 \%$ $(s=0.137)$. Sixteen of the 18 organizations reach a TCR between 31 and $36 \%$. The standard deviation excluding the outlier organization number $17 \quad$ (mean $=34.2 \%$; $s=0.022$ ) implies that the variation within the sample is very low (cf. Fig. 10). The compliance of 16 out of 19 INGO Charter members is in line with a level $\mathrm{C}$ reporting in GRI terms, in which the reporting entity only reports in a selective way and therefore has a low compliance rate.

\section{Discussion and Conclusion}

Principal-agency theory, signaling theory, stakeholder theory and legitimacy theory suggest that INGOs can benefit from a comprehensive SR. A comprehensive disclosure of relevant indicators provides a wider information basis for the users of sustainability reports. A higher compliance rate of INGOs with a reporting standard they have initiated, contributes to the effectiveness of signaling, according to the body of research on voluntary accountability clubs in the NGO sector. From the perspective of stakeholder theory, SR can be seen as an instrument to provide strategically relevant stakeholder information on sustainability performance and thus in return receive their support. In the vein of legitimacy theory, SR can be an instrument to maintain or enhance legitimacy and therefore ensure an INGO's license to operate.

In contrast to the mentioned theories, our analyses showed a rather low compliance rate, far away from a comprehensive reporting, with the exception of one outlier. The overall majority of INGO Charter members did not comply in a satisfying way with the GRI NGO sector supplement they had initiated years before. Normally, one would expect such a reporting behavior in small organizations or first time adopters but not within experienced large INGOs which played a prominent role in initiating and designing the first NGO sector supplement. It can be concluded that INGO Charter members created a sector standard to which they have not complied with in a sufficient way. They neither act as role models, nor are they producing best practice reports which could have been expected from a group who initiated this accountability standard while being a member of the INGO Charter that acknowledge the needs of INGOs to be more accountable. Our findings are more in line with the critical accounting theory with its view that SR is always selective and unbalanced and therefore a comprehensive compliance cannot be expected.

The INGO Charter members' behavior offers a surface of attack because critics could interpret their reporting more as facade building, rather than contributing in a substantive way of making NGOs more accountable with respect to their triple bottom line performance. A low compliance rate is a dubious signal toward other NGOs and across sectors. With this low or selective compliance, the INGO Charter members do not act as promoters of the NGO sector supplement. If key initiators of SR standards, who acknowledge the importance of improving SR of NGOs, do not comply with the standard requirements in a comprehensive way, why should other smaller and less prominent NGOs spend time and resources on this? 


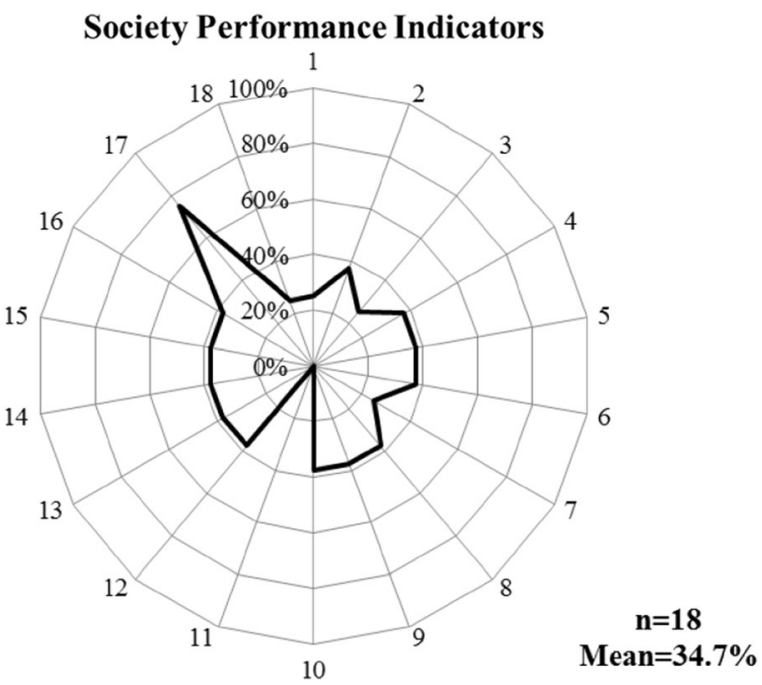

Fig. 8 Society performance indicators

In a cross-sectoral perspective, the low compliance rate is a problematic signal. The idea that NGOs should be following the same SR standards as companies and public sector organizations is not promoted by such a behavior, although an NGO sector supplement exits which adapts sector-neutral GRI standards to sector-specific requirements. This lowers the entrance barriers for NGOs. Despite this situation, the INGO Charter members who initiated the NGO sector supplement comply with this standard only in a selective or non-comprehensive way. As suggested also by others (Crespy and Miller 2011; Simaens and Koster 2013), this raises questions as how seriously SR is taken by the analyzed INGOs. Considering that SR has become an institutionalized practice in large companies, the INGOs which are the NGO sector equivalent to large multinational corporations miss the chance to demonstrate that their reports are as transparent as their multinational counterparts. In that way, our study is in line with the findings of Crespy and Miller (2011) who analyzed 30 randomly selected US NGOs in 2008. Since then, a NGO sector supplement was issued by GRI but without leading to a higher transparency of the sustainability performance.

Looking at the results in more detail, the high compliance rate of program effectiveness is a sign of its importance for the analyzed INGOs. In the past decades, the relevance of upward accountability toward powerful resource providers has increased the reporting requirements for program effectiveness considerably. For program effectiveness INGOs have large specialized departments, which know the rules of the game of program accountability.

If one looks at the compliance rates with respect to the other performance dimensions, one would have expected that the analyzed INGOs would be more transparent. Public

\section{Product Responsibility Performance Indicators}

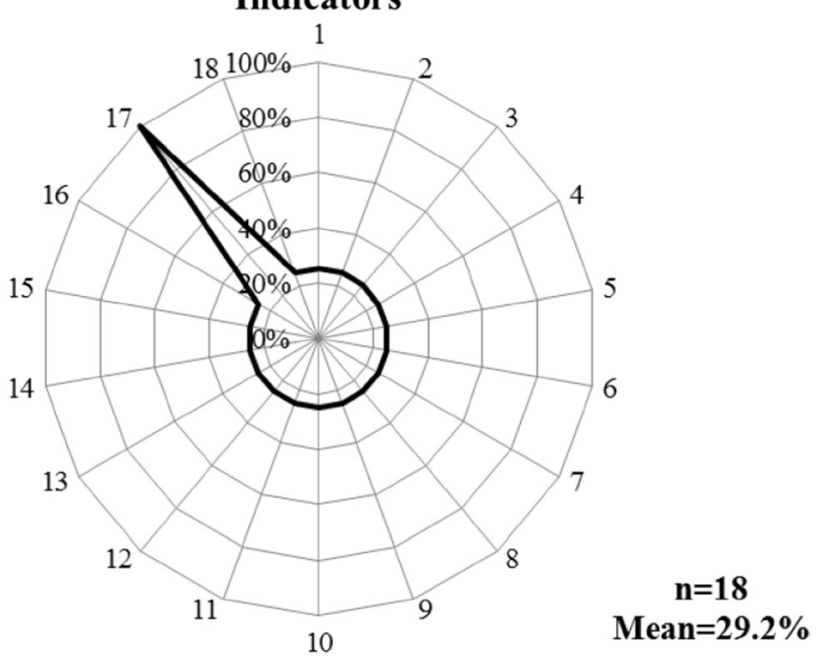

Fig. 9 Product responsibility performance indicators

and private funders nowadays demand a high degree of transparency - that funds are spent efficiently. Unerman and O'Dwyer (2010) regard this as being in the center of upward accountability. Recalling the engaged areas of our sample, a better performance in the area of human rights and regarding environmental issues, although to a lesser degree, would have been expected. To be an advocate for human rights but not report comprehensively on human rights indicators and thus provide no information; for example, the number of incidents of discrimination and the actions that are taken against undermines the credibility. If an INGO believes that a certain indicator is not material or applicable for it, the NGO sector supplement includes the option that an INGO can explain why this indicator is not material or applicable. INGOs should use this option, because otherwise the stakeholders cannot distinguish whether an INGO does not want do disclose this information or the indicator is just not material or applicable for it.

Recalling the theoretical discourses about SR, the following can be stated with respect to information asymmetries. SR of the Charter members provides only a very selective unbalanced insight. As we also coded as 1 if an INGO explained why a specific core indicator is not relevant for it, the reporting practice is far from comprehensive on aspects which designers of the NGO sector supplement regarded as material. The selected disclosures provide only restricted screening possibilities of the INGO Charter members sustainability performance across all traditional categories of the triple bottom line.

The low level of compliance negatively affects the signaling potential of SR. Considering the size and influence the INGO Charter members have and their role as 


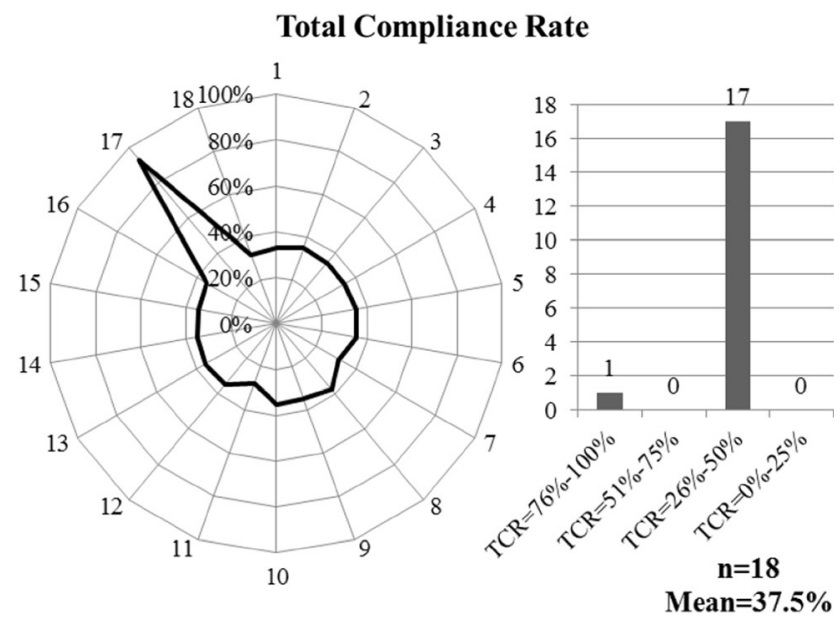

Fig. 10 Total compliance rate

global civil society actors, the lack of transparency does not contribute to reduce accountability pressure stressed by the INGO Charter. Concerning the effectiveness of SR as reputational signaling, the low compliance rate weakens its effectiveness. Unlike large corporations which encounter investors with a focus on sustainability issues and specialized sustainability rating agencies as powerful players and demanding counterparts with sanctioning powers, there are no equally powerful stakeholders for a more comprehensive SR of INGOs. Also a poor compliance in SR of INGOs has not yet attracted the attention of the media.

With respect to stakeholder orientation, the high level of compliance with program effectiveness indictors potentially serves the interested stakeholder groups. The traditional triple bottom line dimensions are reported by most of the Charter members only in a selected way. With such a minimalistic compliance, most of the INGO Charter members miss the opportunity to present themselves as organizations with a professional SR disclosure practices caring for heterogeneous stakeholder information needs. A more comprehensive compliance by the INGO Charter members would provide a more elaborate information basis for their multiple stakeholder audience.

In light of the rising pressures across the sectors for organizations to show more transparent sustainable performance and the self-proclaimed engagement of INGOs for a more sustainable world, the low level of compliance opens a front for criticism. It is too much to say that this provides a serious legitimacy threat for NGOs, but it does not contribute to the credibility of this particular group if they demand from for-profit organizations to be more transparent about their environmental and social performances and have a weak disclosure practice although an NGO sector supplement exits.

In line with critical accounting theory, we encounter a rather selective reporting practice that does not contribute to being fully transparent about the sustainability performance. Such practice, revealing a minimum engagement to the GRI sector standard the INGO Charter helped to create, could give the impression that the Charter members' SR is more in line with organizational hypocrisy than preparing the ground for better sustainability transparency. It is neither in line with transparency expectations which INGOs expect from others, nor does it take into account that the relevance of SR - as major innovation in accounting within the last years-has increased considerably. Thus, there is a discrepancy. On the talk-level INGO Charter members were engaged in initiating the first NGO sector supplement. Against that, on the action level they comply with this standard only in a selective way. A more comprehensive compliance would have shown that SR is an important disclosure tool for multinationals and INGOs alike.

However, it has to be mentioned that comprehensive SR reporting is a resource consuming and complex process. Having a sustainability report in place is not something to be taken for granted within the NGO sector. Therefore, the Charter members have taken a step in the right direction. Continuing down that road could help them in many ways, i.e., to attract new donors, recruit employees and volunteers, offer resistance against critical voices and being a role model for other NGOs, companies and public sector organizations. Studies in other sectors have shown that reporting performance increased over time as well as the pressure from public and private institutions. The future will show to what extent this learning effect would find a way into the reporting practices of the Charter members.

Our study contributes to the literature in the following ways. We add empirical findings to the rather small body of empirical studies of SR of NGOs. The adoption of SR guidelines by NGOs is still in its infancy and rather unbalanced. Here our findings confirm the results of prior studies in the NGO context. To our knowledge, we are offering the first study that analyzes the compliance rates for the GRI NGO sector supplement. Here the INGOs as initiators report only in a selective way. While most studies focus on national or area-specific mandated or voluntary accountability practices of NGOs, we concentrate on INGOs who are important actors in the debate about global governance mechanisms for a more sustainable word. In a cross-sectoral perspective, the voluntary disclosure practice of INGOs in the area of SR has been neglected so far. Our study provides an insight which shows that SR of INGOs is far away from reaching the same degree of institutionalization found in large multinationals. With our multitheory perspectives about reasons and shortcomings of SR, we adapt the general theory-based discourse of SR to the NGO context. Our findings contribute to a multiperspective theory-based critical evaluation of SR. This extends the more selective theoretical approaches of prior studies 
discussing SR of NGOs. Finally, we contribute to the body of research on SR as a major innovation within voluntary accountability initiatives.

One limitation of our study is the static research approach. A longitudinal analysis could explore the development over time and bring to light whether or not the revealed minimalistic reporting behavior changes over time. It is yet another important caveat that compliance with the NGO sector supplement does not say anything about the actual sustainability performance of an INGO. A content analysis of SR can only analyze what is reported, a limitation which we share with other studies in this field. Interviews with the Charter members could help to understand the reasons for the identified reporting patterns and for answering the question of why the Charter members do not use the full potential the NGO sector supplement offers, taking into account that they have initiated the NGO sector supplement. In addition, interviews with powerful stakeholders could help to clarify expectations, information needs and the relevance of SR in comparison to other accountability instruments in the dense web of INGOs external accountability obligations.

Acknowledgements Open access funding provided by Johannes Kepler University Linz.

\section{Compliance with Ethical Standards}

Conflict of interest The authors declare that they have no conflict of interest.

Open Access This article is distributed under the terms of the Creative Commons Attribution 4.0 International License (http://crea tivecommons.org/licenses/by/4.0/), which permits unrestricted use, distribution, and reproduction in any medium, provided you give appropriate credit to the original author(s) and the source, provide a link to the Creative Commons license, and indicate if changes were made.

\section{Appendix}

\begin{tabular}{lll}
\hline \multicolumn{3}{l}{ Standard disclosures of the NGO sector supplement ${ }^{\mathrm{a}}$} \\
\hline Section & Category & Indicators \\
\hline Strategy & Strategy and analysis & $1.1 ; 1.2$ \\
and & Organizational & $2.1 ; 2.2 ; 2.3 ; 2.4 ; 2.5 ; 2.6 ; 2.7 ;$ \\
profile & profile & $2.8 ; 2.9 ; 2.10$ \\
& Reporting parameters & $3.1 ; 3.2 ; 3.3 ; 3.4 ; 3.5 ; 3.6 ; 3.7 ;$ \\
& & $3.8 ; 3.9 ; 3.10 ; 3.11 ; 3.12 ; 3.13$ \\
& Governance, & $4.1 ; 4.2 ; 4.3 ; 4.4 ; 4.5 ; 4.6 ; 4.7 ;$ \\
& commitments and & $4.8 ; 4.9 ; 4.10 ; 4.11 ; 4.12 ; 4.13 ;$ \\
& engagement & $4.14 ; 4.15 ; 4.16 ; 4.17$ \\
\hline
\end{tabular}

\begin{tabular}{|c|c|c|c|}
\hline \multirow{3}{*}{\multicolumn{2}{|c|}{$\begin{array}{l}\text { Section } \\
\text { Disclosure on management } \\
\text { approaches }\end{array}$}} & \multicolumn{2}{|l|}{ Category } \\
\hline & & \multirow{7}{*}{\multicolumn{2}{|c|}{$\begin{array}{l}\text { DMA program effectiveness } \\
\text { DMA economic } \\
\text { DMA environmental } \\
\text { DMA labor practices and } \\
\text { decent work } \\
\text { DMA human rights } \\
\text { DMA society } \\
\text { DMA product responsibility }\end{array}$}} \\
\hline & & & \\
\hline & & & \\
\hline & & & \\
\hline & & & \\
\hline & & & \\
\hline & & & \\
\hline Section & Category & Aspect & Indicators $^{\mathrm{b}}$ \\
\hline \multirow[t]{15}{*}{$\begin{array}{l}\text { Performance } \\
\text { indicators }\end{array}$} & $\begin{array}{l}\text { Program } \\
\text { effectiveness }\end{array}$ & $\begin{array}{l}\text { Affected } \\
\text { stakeholder } \\
\text { engagement }\end{array}$ & NGO1 \\
\hline & & $\begin{array}{l}\text { Feedback, } \\
\text { complaints and } \\
\text { action }\end{array}$ & NGO2 \\
\hline & & $\begin{array}{l}\text { Monitoring, } \\
\text { evaluation and } \\
\text { learning }\end{array}$ & NGO3 \\
\hline & & $\begin{array}{c}\text { Gender and } \\
\text { diversity }\end{array}$ & NGO4 \\
\hline & & $\begin{array}{c}\text { Public awareness } \\
\text { and advocacy }\end{array}$ & NGO5 \\
\hline & & Coordination & NGO6 \\
\hline & Economic & Resource allocation & NGO7 \\
\hline & & Ethical fundraising & NGO8 \\
\hline & & $\begin{array}{l}\text { Economic } \\
\text { performance }\end{array}$ & $\begin{array}{r}\text { EC1; EC2; } \\
\text { EC3; EC4 }\end{array}$ \\
\hline & & $\begin{array}{l}\text { Market presence, } \\
\text { including impact } \\
\text { on local } \\
\text { economies }\end{array}$ & $\begin{array}{l}\text { EC5; EC6; } \\
\text { EC7 }\end{array}$ \\
\hline & & $\begin{array}{l}\text { Indirect economic } \\
\text { impacts }\end{array}$ & EC8; EC9 \\
\hline & Environmental & Materials & EN1; EN2 \\
\hline & & Energy & $\begin{array}{l}\text { EN3; EN4; } \\
\text { EN5; EN6; } \\
\text { EN7 }\end{array}$ \\
\hline & & Water & $\begin{array}{l}\text { EN8; EN9; } \\
\text { EN10 }\end{array}$ \\
\hline & & Biodiversity & $\begin{array}{l}\text { EN11; } \\
\text { EN12; } \\
\text { EN13; } \\
\text { EN14; } \\
\text { EN15 }\end{array}$ \\
\hline
\end{tabular}




\begin{tabular}{|c|c|c|c|}
\hline Section & Category & Aspect & Indicators $^{\mathrm{b}}$ \\
\hline & & $\begin{array}{l}\text { Emissions, effluents } \\
\text { and waste }\end{array}$ & $\begin{array}{r}\text { EN16; EN17; } \\
\text { EN18; EN19; } \\
\text { EN20; EN21; } \\
\text { EN22; EN23; } \\
\text { EN24; EN25 }\end{array}$ \\
\hline & & $\begin{array}{l}\text { Products and } \\
\text { services }\end{array}$ & EN26; EN27 \\
\hline & & Compliance & EN28 \\
\hline & & Transport & EN29 \\
\hline & & Overall & EN30 \\
\hline \multicolumn{4}{|c|}{ Social } \\
\hline & \multirow{6}{*}{$\begin{array}{l}\text { Labor } \\
\text { practices and } \\
\text { decent work }\end{array}$} & Employment & $\begin{array}{l}\text { LA1; LA2; LA3; } \\
\text { LA15 }\end{array}$ \\
\hline & & $\begin{array}{l}\text { Labor/management } \\
\text { relations }\end{array}$ & NG09; LA4; LA5 \\
\hline & & $\begin{array}{l}\text { Occupational health } \\
\text { and safety }\end{array}$ & $\begin{array}{l}\text { LA6; LA7; LA8; } \\
\text { LA9 }\end{array}$ \\
\hline & & $\begin{array}{l}\text { Training and } \\
\text { education }\end{array}$ & $\begin{array}{l}\text { LA10; LA11; } \\
\text { LA12; }\end{array}$ \\
\hline & & $\begin{array}{l}\text { Diversity and equal } \\
\text { opportunity }\end{array}$ & LA13 \\
\hline & & $\begin{array}{l}\text { Equal remuneration } \\
\text { for women and } \\
\text { men }\end{array}$ & LA14 \\
\hline & \multirow[t]{9}{*}{ Human rights } & $\begin{array}{l}\text { Investment and } \\
\text { procurement } \\
\text { practices }\end{array}$ & HR1; HR2; HR3 \\
\hline & & Non-discrimination & HR4 \\
\hline & & $\begin{array}{l}\text { Freedom of } \\
\text { association and } \\
\text { collective } \\
\text { bargaining }\end{array}$ & HR5 \\
\hline & & Child labor & HR6 \\
\hline & & $\begin{array}{l}\text { Forced and } \\
\text { compulsory labor }\end{array}$ & HR7 \\
\hline & & Security practices & HR8 \\
\hline & & Indigenous rights & HR9 \\
\hline & & Assessment & HR10 \\
\hline & & Remediation & HR11 \\
\hline & \multirow[t]{5}{*}{ Society } & (Local) community & SO1; SO9; SO10 \\
\hline & & Corruption & SO2; SO3; SO4 \\
\hline & & Public policy & SO5; SO6 \\
\hline & & $\begin{array}{l}\text { Anti-competitive } \\
\text { behavior }\end{array}$ & SO7 \\
\hline & & Compliance & SO8 \\
\hline & $\begin{array}{l}\text { Product } \\
\text { responsibility }\end{array}$ & $\begin{array}{l}\text { Customer health } \\
\text { and safety }\end{array}$ & PR1; PR2 \\
\hline
\end{tabular}

\begin{tabular}{|c|c|c|c|}
\hline Section & Category & Aspect & Indicators $^{\mathrm{b}}$ \\
\hline & & Product and service labeling & PR3; PR4; PR5 \\
\hline & & Marketing communications & PR6; PR7 \\
\hline & & Customer privacy & PR8 \\
\hline & & Compliance & PR9 \\
\hline
\end{tabular}

${ }^{\text {a Standard disclosures of the NGO sector supplement expanded by the }}$ G3.1 Indicators

${ }^{\mathrm{b}}$ Core indicators are written in bold

\section{References}

Abrahamson, E., \& Baumgard, P. (2008). What lies behind organizational façades and how organizational façades lie: An untold story of organizational decision making. In G. P. Hodgkinson \& W. H. Starbuck (Eds.), The Oxford handbook on organizational decision making (pp. 437-452). Oxford: Oxford University Press.

Accountable Now (2017). About Accountable Now. Available at: https://accountablenow.org/about-accountable-now/. Accessed 5 Sept 2017.

Baker, M. (2010). Re-conceiving managerial capture. Accounting, Auditing \& Accountability Journal, 23, 847-867.

Bovens, M. (2007). Analysing and assessing accountability: A conceptual framework. European Law Journal, 13, 447-469.

Burritt, R. L., \& Schaltegger, S. (2010). Sustainability accounting and reporting: Fad or trend? Accounting, Auditing \& Accountability Journal, 23, 829-846.

Carman, J. G. (2007). Evaluation practice among community-based organizations: Research into the reality. American Journal of Evaluation, 28, 60-75.

INGO Accountability Charter (2015a). What is the Charter?. Available at: http://www.ingoaccountabilitycharter.org/home/what-isthe-charter/. Accessed 1 July 2015.

INGO Accountability Charter (2015b). INGO Accountability Charter Reporting Requirements. Available at: http://www.ingoaccount abilitycharter.org/wpcms/wp-content/uploads/Charter-Report ing-Requirements_Feb-2015.pdf. Accessed 1 July 2015.

INGO Accountability Charter (2015c). Membership Criteria and Fees. Available at: http://www.ingoaccountabilitycharter.org/ home/membership-criteria/. Accessed 1 July 2015.

Cho, Ch H, Laine, M., Roberts, R. W., \& Rodrigue, M. (2015). Organized hypocrisy, organizational façades, and sustainability reporting. Accounting, Organizations and Society, 40, 79-94.

Comyns, B., \& Figge, F. (2015). Greenhouse gas reporting quality in the oil and gas industry, a longitudinal study using the typology of "search", "experience" and "credence" information. Accounting, Auditing \& Accountability Journal, 28, 403-433.

Comyns, B., Figge, F., Hahn, T., \& Barkemeyer, R. (2013). Sustainability reporting: The role of "search", "experience" and "credence" information. Accounting Forum, 37, 231-243.

Conway, S. L., O’Keefe, P. A., \& Hrasky, S. L. (2015). Legitimacy, accountability and impression management in NGOs: The Indian Ocean Tsunami. Accounting, Auditing and Accountability Journal, 28, 1075-1098.

Crack, A. M. (2017). The regulation of international NGOS: Assessing the effectiveness of the INGO accountability charter. Voluntas, published online 4 April 2017, pp. 1-19.

Cragg, W. (2002). Business ethics and stakeholder theory. Business Ethics Quarterly, 12, 113-142. 
Crespy, C. T., \& Miller, V. V. (2011). Sustainability reporting: A comparative study of NGOs and MNCs. Corporate Social Responsibility and Environmental Management, 18, 275-284.

Deegan, C. (2014). An Overview of legitimacy theory as applied within the social and environmental accounting literature. In J. Bebbington, J. Unerman, \& B. O'Dwyer (Eds.), Sustainability accounting and accountability (pp. 248-272). Milton Park and New York: Routledge.

Dhanani, A., \& Connolly, C. (2015). Non-governmental organizational accountability: Taking the talk and walking the walk? Journal of Business Ethics, 129, 613-637.

Doh, J. P., \& Teegen, H. (2002). Nongovernmental organizations as institutional actors in international business: Theory and implications. International Business Review, 11, 665-684.

Dowling, J., \& Pfeffer, J. (1975). Organizational legitimacy: Social values and organizational behaviour. Pacific Sociological Review, 18, 122-136.

Ebrahim, A. (2010). The many faces of nonprofit accountability. In D. Renz (Ed.), The handbook of nonprofit management and leadership (pp. 101-121). San Francisco: Wiley.

Edwards, M., \& Fowler, A. (2002). Introduction: Changing challenges for NGDO management. In M. Edwards \& A. Fowler (Eds.), The Earthscan reader on NGO management (pp. 1-11). London: Routledge.

Freeman, R. E. (1984). Strategic management: A stakeholder approach. Boston MA: Pitman.

Freeman, R. E. (1994). The politics of stakeholder theory: Some further directions. Business Ethics Quarterly, 4, 409-421.

Freeman, R. E. (2010). Strategic management, a stakeholder approach. Cambridge: Cambridge University Press.

Freeman, R. E., Wicks, A. C., \& Parmar, P. (2004). Stakeholder theory and "the corporate objective revisited". Organizational Science, 15, 364-369.

Gatti, L., \& Seele, P. (2014). Evidence for the prevalence of the sustainability concept in European corporate responsibility reporting. Sustainability Science, 9, 89-102.

Global Reporting Initiative GRI (2010). Sustainability Reporting Guidelines \& NGO Sector Supplement. Available at: https:// www.globalreporting.org/resourcelibrary/G3-English-NGO-Sec tor-Supplement.pdf. Accessed 1 May 2015.

Global Reporting Initiative GRI (2014). G4 Sector Disclosures NGO. Available at: https://www.globalreporting.org/resourcelibrary/ GRI-G4-NGO-Sector-Disclosures.pdf. Accessed 1 Sept 2016.

Global Reporting Initiative GRI (2017). About Sustainability Reporting. Available at: https://www.globalreporting.org/information/ sustainability-reporting/Pages/default.aspx. Accessed 1 Sept 2017.

Goswami, K., \& Lodhia, S. (2014). Sustainability disclosure patterns of South Australian local Councils: A case study. Public Money \& Management, 34, 273-280.

Gray, R. (2010). Is accounting for sustainability actually accounting for sustainability... and how would we know? An exploration of narratives of organisations and the planet. Accounting, Organizations and Society, 35, 47-62.

Gray, R. (2013). Back to the basics: What do we mean by environmental (and social accounting) and what is it for?-A reaction to Thornton. Critical perspectives on Accounting, 24, 459-468.

Gray, R., Kouhy, R., \& Lavers, S. (1995). Corporate social and environmental reporting: A review of the literature and a longitudinal study of UK disclosure. Accounting, Auditing \& Accountability Journal, 8, 47-77.

Gray, R., \& Milne, M. J. (2002). Sustainability reporting: Who's kidding whom? Chartered Accountants Journal of New Zealand, $81,66-74$
Greiling, D., \& Stötzer, S. (2015). Performance accountability as a driver for changes in nonprofit-government relationships: An empirical insight from Austria. VOLUNTAS: International Journal of Voluntary and Nonprofit Organizations, 26, 1690-1717.

Greiling, D., Traxler, A. A., \& Stötzer, S. (2015). Sustainability reporting in the Austrian, German and Swiss public sector. International Journal of Public Sector Management, 28, 404-428.

Gugerty, M. K. (2009). Signaling virtue: Voluntary accountability programs among nonprofit organizations. Policy Sciences, 42, 243-273.

Guidry, R. P., \& Patten, D. M. (2010). Market reactions to the firsttime issuance of corporate sustainability reports: Evidence that quality matters. Sustainability Accounting, Management and Policy Journal, 1, 33-50.

Guthrie, J., \& Abeysekera, I. (2006). Content analysis of social, environmental reporting: What is new? Journal of Human Resource Costing \& Accounting, 10, 114-126.

Guthrie, J., \& Farneti, F. (2008). GRI sustainability reporting by Australian public sector organizations. Public Money and Management, 28, 361-366.

Hahn, R., \& Kühnen, M. (2013). Determinants of sustainability reporting: A review of results, trends, theory, and opportunities in an expanding field of research. Journal of Cleaner Production, $59,5-21$.

Hopwood, A. G. (2009). Accounting and the environment. Accounting, Organization and Society, 34, 433-439.

Kolk, A. (2008). Sustainability, accountability and corporate governance: Exploring multinationals' reporting practices. Business Strategy and the Environment, 17, 1-15.

Kolk, A. (2010). Trajectories of sustainability reporting by MNCs. Journal of World Business, 45, 367-374.

KPMG International (2015). The KPMG Survey of Corporate Responsibility Reporting 2015, Currents of Change. Available at: https://assets.kpmg.com/content/dam/kpmg/pdf/2016/02/ kpmg-international-survey-of-corporate-responsibility-report ing-2015.pdf. Accessed 6 Sept 2017.

Lecy, J. D., Schmitz, H. P., \& Swedlund, H. (2012). Nongovernmental and not-for-profit organizational effectiveness: A modern synthesis. VOLUNTAS: International Journal of Voluntary and Nonprofit Organizations, 23, 434-457.

Lozano, R. (2013). Sustainability inter-linkages in reporting vindicated: A study of European companies. Journal of Cleaner Production, 51, 57-65.

Lyon, T. P., \& Maxwell, J. W. (2011). Greenwash: Corporate environmental disclosure under threat of audit. Journal of Economics \& Management Strategy, 20, 3-41.

Mahoney, L. S., Thorne, L. C., Cecil, L., \& LaGore, W. (2013). A research note on standalone corporate social responsibility reports: Signaling or greenwashing? Critical Perspectives on Accounting, 24, 350-359.

Manetti, G., \& Toccafondi, S. (2014). Defining the content of sustainability reports in nonprofit organizations: Do stakeholders really matter? Journal of Nonprofit \& Public Sector Marketing, 26, 35-61.

Milne, M. J., \& Adler, R. W. (1999). Exploring the reliability of social and environmental disclosures content analysis. Accounting, Auditing \& Accountability Journal, 12, 237-256.

Murtaza, N. (2012). Putting the lasts first: The case for communityfocused and peer-managed NGO accountability mechanisms. VOLUNTAS: International Journal of Voluntary and Nonprofit Organizations, 23, 109-125.

Prakash, A., \& Gugerty, M. K. (2010). Trust but verify? Voluntary regulation programs in the nonprofit sector. Regulation \& Governance, 4, 22-47. 
Salamon, L. M., Hems, L. C., \& Chinnock, K. (2000). The nonprofit sector: For what and for whom?. Working Papers of the Johns Hopkins Comparative Nonprofit Sector Project. Available at: http://thirdsectorimpact.eu/site/assets/uploads/page/documentsfor-researchers/CNP_WP37_2000.pdf. Accessed 1 Feb 2017.

Schmitz, H. P., Raggo, P., \& Bruno-van Vijfeijken, T. (2012). Accountability of transnational NGOs: Aspirations vs practice. Nonprofit and Voluntary Sector Quarterly, 41, 1175-1194.

Schwindenhammer, S. (2013). Patterns and explanations of corporate voluntary norm compliance: Results from a structured focussed comparison of German G500 in the global reporting initiative. German Policy Studies, 9, 123-160.

Simaens, A., \& Koster, M. (2013). Reporting on sustainable operations by third sector organizations: A signalling approach. Public Management Review, 15, 1040-1062.

Smith, S. R. (2010a). Nonprofits and public administration: Reconciling performance management and citizen engagement. The American Review of Public Administration, 40, 129-152.

Smith, S. R. (2010b). Nonprofit organizations and government: Implications for policy and practice. Journal of Policy Analysis and Management, 29, 621-625.

Spence, M. (1973). Job market signaling. Quarterly Journal of Economics, 87, 355-374.
Tremblay-Boire, J., \& Prakash, A. (2015). Accountability.org: Online disclosures by U.S. nonprofits. VOLUNTAS: International Journal of Voluntary and Nonprofit Organizations, 26, 693-719.

Tremblay-Boire, J., Prakash, A., \& Gugerty, M. K. (2016). Regulation by reputation: Monitoring and sanctioning in nonprofit accountability clubs. Public Administration Review, 76, 712-722.

Unerman, J., \& O'Dwyer, B. (2006). Theorising accountability for NGO advocacy. Accounting, Auditing \& Accountability Journal, 19, 349-376.

Unerman, J., \& O'Dwyer, B. (2010). NGO accountability and sustainability issues in the changing global environment. Public Management Review, 12, 475-486.

Van der Laan Smith, J., Adhikari, A., \& Tondkar, R. H. (2005). Exploring differences in social disclosures internationally: A stakeholder perspective. Journal of Accounting and Public Policy, 24, 123-151.

Verrecchia, R. E. (1983). Discretionary disclosure. Journal of Accounting and Economics, 3, 179-194.

Walton, O. E., Davies, T., Thrandardottir, E., \& Keating, V. C. (2016). Understanding contemporary challenges to INGO legitimacy: Integrating top-down and bottom-up perspectives. VOLUNTAS: International Journal of Voluntary and Nonprofit Organizations, 27, 2764-2786. 